International Journal of Agriculture, Environment and Bioresearch

Vol. 5, No. 03; 2020

ISSN: $2456-8643$

\title{
RISK ANALYSIS OF FORMALDEHYDE EMISSIONS IN MORTUARIES CASE STUDY OF FIVE MORTUARIES INSIDE A FACULTY OF MEDICINE IN EGYPT
}

\author{
*Ashraf A. Zahran \\ *Department of Natural Resources and Planning to Development, Environmental Studies and Research Institute, \\ University of Sadat City, Sadat City, Egypt \\ https://doi.org/10.35410/IJAEB.2020.5511
}

\begin{abstract}
Formaldehyde is a volatile organic compound that has serious effects on human health and considered a human carcinogen based on sufficient human and animal inhalation studies. In mortuaries, formaldehyde is commonly used for the preservation of the dead. Formaldehyde was measured during working hours in March 2018 in five mortuaries in Egypt. Formaldehyde recorded $1.69 \pm 0.72,1.80 \pm 0.69,0.94 \pm 0.56,1.08 \pm 0.33$, and $0.13 \pm 0.05 \mathrm{ppm}$ in the five mortuaries. These concentrations exceeded air quality limits of the Egyptian Environmental Affairs Agency $(0.3 \mathrm{ppm})$ in all sites except the 5th mortuary and exceeded air quality limits of the National Institute for Occupational Safety and Health in all sites (0.016. ppm). Hazard Rating Number system is used in this work as a simple tool to assess the risk of exposure to formaldehyde in mortuaries and recorded high levels of risk in most cases. The study indicated that Hazard Rating Number system can be used as a preliminary risk assessment tool that can be calculated by non-specialists to take decisions when high formaldehyde concentration is detected. According to the risk control hierarchy, there are several control options that need further scientific studies such as using virtual reality and augmented reality, decreasing noise of ventilation systems, and substitution of formaldehyde by other preservative solutions to decrease the risk of exposure to formaldehyde in mortuaries. Finally, the study focused on the serious need for risk communication activities to increase awareness of workers and students about formaldehyde health risk.
\end{abstract}

Keywords: Formaldehyde; Hazard rating number system; Indoor Air Pollution; Risk assessment; Ventilation.

\section{INTRODUCTION}

Formaldehyde (FA) is a volatile organic compound (VOC) with the formula $\mathrm{CH}_{2} \mathrm{O}$. It is the simplest form of aldehydes (Alessandro et al.,2019). FA is a colorless, flammable gas that has a distinct, pungent smell at room temperature. Small amounts of FA are naturally produced by plants, animals, and humans. FA has serious effects on human health. Nasal and eye irritation, neurological effects, and increased risk of asthma and/or allergy have been observed at 0.1 and $0.5 \mathrm{ppm}$. Eczema and changes in lung function have been observed at 0.6 to $1.9 \mathrm{ppm}$. Decreased body weight, gastrointestinal ulcers, liver and kidney damage were observed in animals orally exposed to 50-100 milligrams/kilogram/day (mg/kg/day) FA. The International Agency for Research on Cancer (IARC) has classified formaldehyde as carcinogenic to humans (Group 1) as 
there is sufficient evidence in humans and experimental animals for the carcinogenicity of formaldehyde (IARC, 2012). Also, the United States Department of Health and Human Services (HHS) determined in 2011 that FA is a known human carcinogen based on sufficient human and animal inhalation studies by Agency for Toxic Substances and Disease Registry (ATSDR),2015).Work-related contact with FA happens in a multiplicity of diverse areas, although employees at greater risk are those engaged in the healthcare areas (specially mortuaries) and in wood treating manufacturing (Alessandro et al.,2019; Scarselli et al.,2017). The hospital environment is complex and presents a large number of risks for its workers. Generally, in a hospital, there is exposure to nonspecific risk factors (such as falling off a ladder or slippery pavement) that may arise in any other work environment and more specific risk factors (bites, cuts or perforations with potentially infected sharps), relevant biological agents, chemical exposure, ionizing and non-ionizing radiation, mechanical factors, as well as ergonomic issues such as the continued manual movement of dependent patients. The risk of a healthcare professional contracting work-related illness is about 1.5 times greater than the risk of all other workers. In mortuaries, FA is commonly used for the preservation (embalmment) of the dead. Mortuary workers and medical students are exposed daily to FA by inhalation and skin contact (Sousa et al.,2017; Obed-Whyte et al.,2019).The term risk analysis is used by World Health Organization (WHO) and Food and Agriculture Organization (FAO) to encompass all components of risk; risk assessment, risk management, and risk communication (Fig. 1) (Nauta et al.,2018).Office of the Gene Technology Regulator (OGTR) defined risk assessment as a science-based component that identifies risks from plausible sets of circumstances that may result in harm to people or to the environment and estimating the level of risk on the basis of the seriousness and chance of harm, while risk management is identified as a Policy-based component that evaluates, selects, and implements plans or actions to ensure risks are appropriately managed (OGTR, 2009). According to National Institute for Occupational Safety and Health (NIOSH), risks can be managed as shown in Fig. 2by removing the hazard, replacing the hazard, isolating people from the hazard, changing the way people work, and/or protecting workers with personal protective equipment (PPEs) respectively (NIOSH, 2015). Risk communication is the exchange of information, ideas, and views between the regulator and stakeholders; it also conveys the rationale foe decisions made by the regulator (OGTR, 2009).

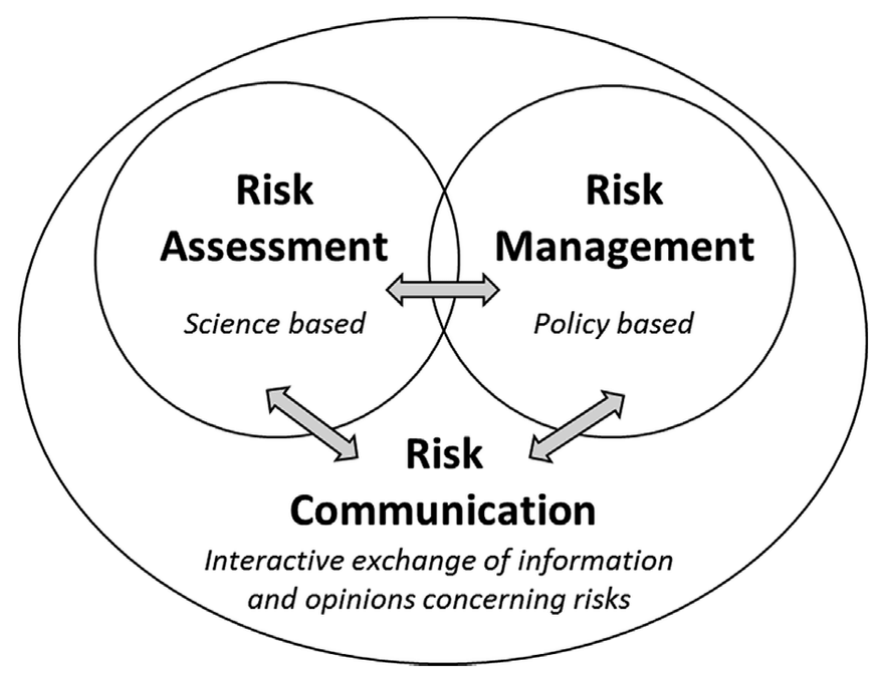


Fig. 1: The risk analysis framework with the elements risk assessment, Risk management and risk communication (Nauta et al., 2018)

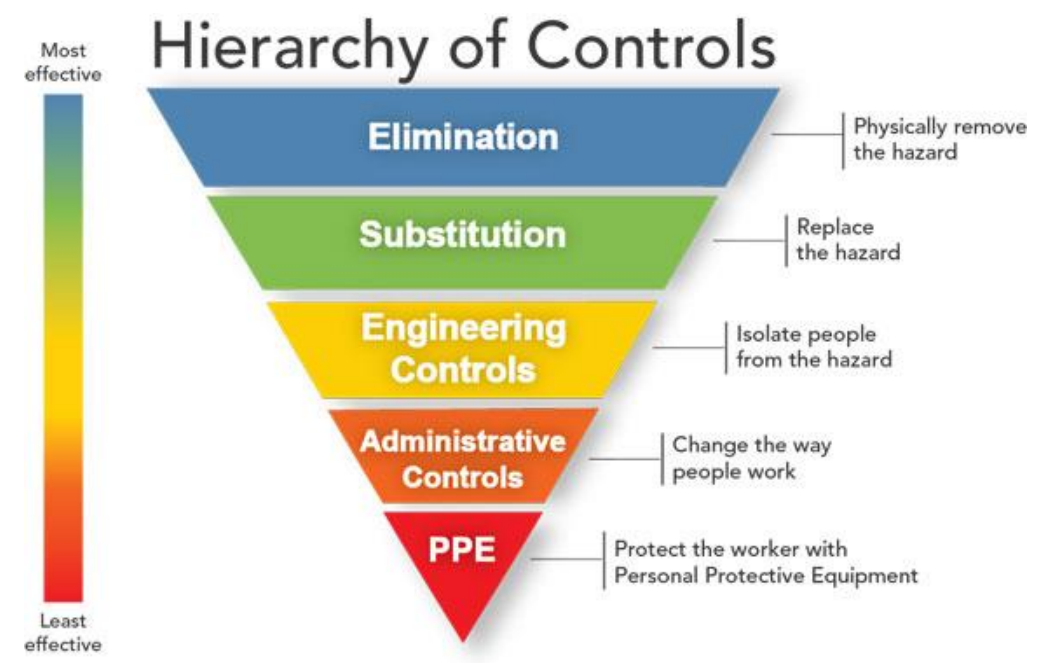

Fig. 2: Hierarchy of Controls (NIOSH, 2015)

This study aims to compare FA concentrations in the working environment of five mortuaries in Egypt with exposure limits of national authorities, international organizations, and the results of other studies. Also, this study aims to assess the risk of exposure to FA in these mortuaries and explore the different options to control this risk. This study has been carried out in five mortuaries inside a faculty of medicine in Egypt in 2018.

\section{MATERIALS AND METHODS}

\section{FA measurements}

FA was measured during working hours in five mortuaries in Egypt using First Check which is an intrinsically safe portable gas detector, designed for the detection of numerous gases such as (TVOC's, FA, Xylene, Butanol, ...etc.) and others hydrocarbon fuels, solvents, semi-conductor gases using photoionization detector (PID). A small internal pump draws gas through the Photo Check probe and through a PID cell. Ultraviolet (UV) light from the photic lamp penetrates and converts some of the gas within the PID cell into positive and negative ions. These are then separated electrically within the cell into a detectable current, which is particularly large for hydrocarbon gases present. The photo-ionization current is amplified and scaled for display as a concentration, either ppb or $\mathrm{ppm}$ or $\mathrm{mg} / \mathrm{m}^{3}$ units for a specific target gas and photic lamp combination (Ion science, 2009). 


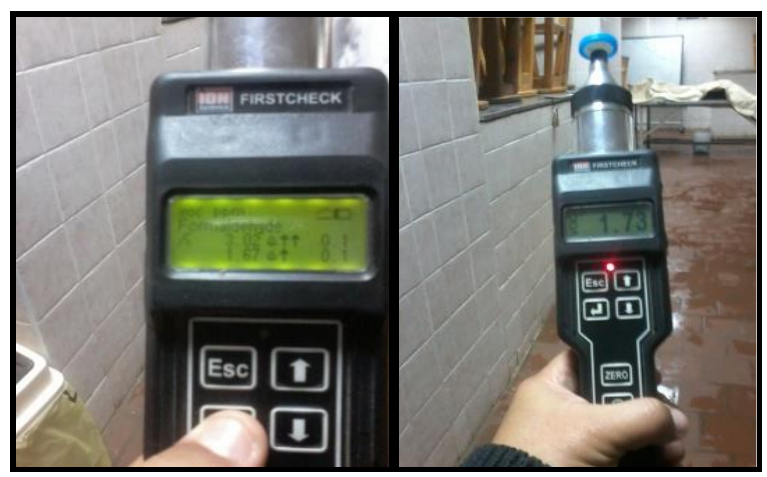

Fig. 3: Used instrument for FA measurements (First Chick)

Air quality limits (AQLs)

Results of FA measurements were compared to AQLs which approved by National Institute for Occupational Safety and Health (NIOSH), Occupational Safety and Health Administration (OSHA), and Egyptian Environmental Affairs Agency (EEAA). Table 1 shown Short Term Exposure Limits (STEL), Time-weighted Average (TWA), and Ceiling borders for FA in part per millions (ppm). NIOSH considers formaldehyde to be a potential occupational carcinogen and hence adopted lower limits (NIOSH,2007; EEAA, 2011).

Table 1: AQLs of FA according to exposure time

\begin{tabular}{|lcccccc|}
\hline & \multicolumn{3}{c}{ OSHA } & & & \\
\hline \multirow{2}{*}{ Pollutant } & \multicolumn{2}{c}{ NIOSH } & & EEAA \\
\cline { 2 - 6 } & STEL & TWA8 & 15 min. (Ceiling) & TWA8 & Ceiling border \\
\hline Formaldehyde(ppm) & 2 & 0.75 & 0.1 & 0.016 & 0.3 \\
\hline
\end{tabular}

\section{Ventilation in mortuaries}

Ventilation rates in these five mortuaries were calculated from the suction system capacity in each mortuary and compared to EEAA acceptable limits as shown in Table 2(EEAA, 2011). Mortuaries were not included in the law and hence were considered as a science lab because of the presence of practical sections for students of medical faculty. 
International Journal of Agriculture, Environment and Bioresearch

Vol. 5, No. 03; 2020

ISSN: $2456-8643$

Table 2: Minimum required ventilation rate for public and closed places

\begin{tabular}{|c|c|c|c|}
\hline No. & Place/ Activity & $\begin{array}{l}\text { Occupancy density } \\
\text { (person/100 } \mathrm{m}^{2} \text { ) }\end{array}$ & $\begin{array}{l}\text { Minimum Ventilation Rate } \\
\text { (liter/second/person) }\end{array}$ \\
\hline 1 & $\begin{array}{l}\text { Education places: } \\
\qquad \begin{array}{l}\text { - Small lecture room } \\
\text { - Lecture hall } \\
\text { - Science lab }\end{array}\end{array}$ & 65 & 4.3 \\
\hline 2 & $\begin{array}{l}\text { Restaurants and cafeterias: } \\
\text { - Restaurants (eating rooms) } \\
\text { - Cafeteria / fast food places }\end{array}$ & 50 & 10 \\
\hline 3 & $\begin{array}{l}\text { Hotels and Resorts: } \\
\begin{array}{l}\text { - Bedrooms / living } \\
\text { - Entrance foyer / saloons }\end{array}\end{array}$ & 10 & 8.4 \\
\hline 4 & $\begin{array}{l}\text { Administrative Buildings: } \\
\text { - Office room } \\
\text { - Reception area / main entrance } \\
\text { foyer } \\
\text { - Meetings Hall } \\
\text { - Conferences Hall }\end{array}$ & $\begin{array}{l}5 \\
30 \\
50\end{array}$ & $\begin{array}{l}10 \\
5.5 \\
8\end{array}$ \\
\hline 5 & $\begin{array}{l}\text { Gatherings places: } \\
\text { - Concert halls Cinema Theater } \\
\text { - Public libraries } \\
\text { - Museums } \\
\text { - Exhibitions }\end{array}$ & $\begin{array}{l}10 \\
10\end{array}$ & $\begin{array}{c}8 \\
8.5\end{array}$ \\
\hline 6 & $\begin{array}{l}\text { Fun /sports places: } \\
\text { - Indoor games halls (onlookers) } \\
\text { - Health Club (Aerobics) } \\
\text { - Gymnasiums }\end{array}$ & $\begin{array}{l}100 \\
40\end{array}$ & 8 \\
\hline \multicolumn{4}{|c|}{$\begin{aligned} \text { Notes: - The above limits are acceptable if smoking is prohibited in these places. } \\
\\
\text { - Occupancy density is used when the actual occupancy density not available. }\end{aligned}$} \\
\hline
\end{tabular}




\section{Risk assessment}

There are numerous ways of assessing the risk involved with a hazard. The Hazard Rating Number system (HRN) used in this work as a simple tool for risk assessment of exposure to FA in five mortuaries in Egypt. A key to the number system is detailed in Tables 3. HRN can be calculated according to eq. 1 . H. R.N. = LO $*$ FE $*$ DPH $*$ NP

Where LO is the likelihood of occurrence, FE is the frequency of exposure, DPH is the degree of possible harm, and NP is the number of persons at risk (TÜV SÜD Product Service, 2015).

Table 3: Hazard rating number system (HRN)

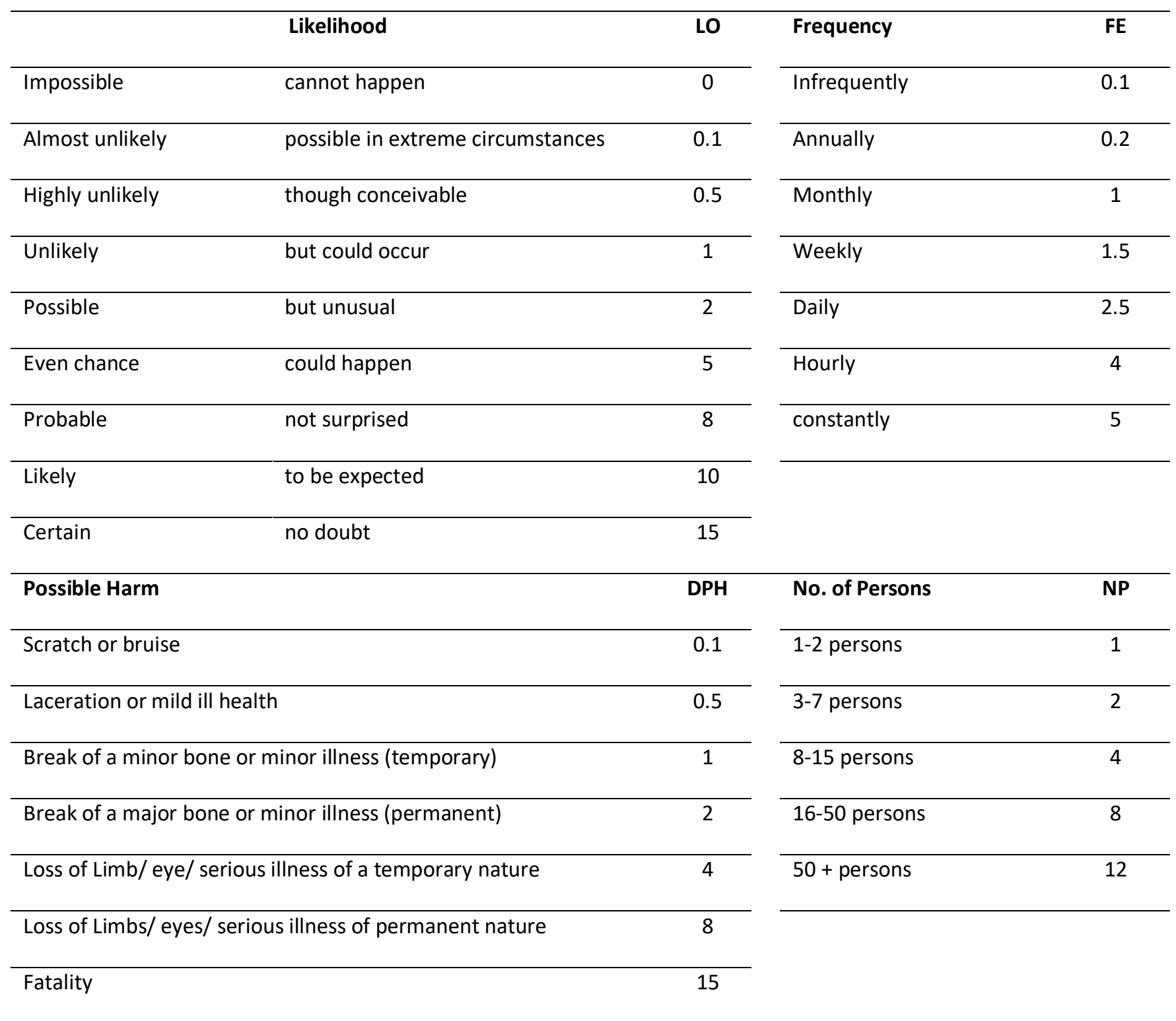


International Journal of Agriculture, Environment and Bioresearch

Vol. 5, No. 03; 2020

ISSN: $2456-8643$

\begin{tabular}{|ccccccccc|}
\hline RISK & Negligible & Very Low & Low & Significant & High & Very High & Extreme & Unacceptable \\
\hline HRN & $0-1$ & $1-5$ & $5-10$ & $10-50$ & $50-100$ & $100-500$ & $500-1000$ & Over 1000 \\
\hline
\end{tabular}

Table 4: Appropriate time for corrective actions (SHP, 2015)

\begin{tabular}{|c|c|c|}
\hline HRN & RISK & Action time table \\
\hline $0-1$ & Negligible & Accept Risk \\
\hline $1-5$ & Very Low & Action within 1 year \\
\hline $5-10$ & Low & Action within 3 months \\
\hline $10-50$ & Significant & Action within 1 month \\
\hline $50-100$ & High & Action within 1 week \\
\hline $100-500$ & Very High & Action within 1 day \\
\hline $500-1000$ & Extreme & Immediate Action \\
\hline Over 1000 & Unacceptable & Stop the activity \\
\hline
\end{tabular}

DPH was modified by the author according to expected health impacts related to FA concentrations and TWA 8 limits of several organizations and developed countries as shown in Table 5. 
International Journal of Agriculture, Environment and Bioresearch

Vol. 5, No. 03; 2020

ISSN: $2456-8643$

Table 5: DPH for FA inhalable concentrations

\begin{tabular}{|c|c|c|c|}
\hline $\mathrm{TWA}_{8}$ limits & $\begin{array}{c}\text { Suggested FA } \\
\text { range (by author) }\end{array}$ & Possible health harm & $\mathrm{DPH}$ \\
\hline & $<0.016 \mathrm{ppm}$ & & 0.1 \\
\hline NIOSH (0.016 ppm) (NIOSH, 2007) & $0.016-0.1 \mathrm{ppm}$ & & 0.5 \\
\hline & $0.1-0.3 \mathrm{ppm}$ & $\begin{array}{l}\text { Nasal and eye irritation, neurological effects, and } \\
\text { increased risk of asthma and/or allergy have been }\end{array}$ & 1 \\
\hline $\begin{array}{l}\text { Finland and Germany }(0.3 \mathrm{ppm}) \\
\text { (Kim et al., 2011) }\end{array}$ & $0.3-0.5 \mathrm{ppm}$ & $\begin{array}{l}\text { observed in humans breathing } 0.1 \text { to } 0.5 \mathrm{ppm} \text { (ATSDR, } \\
\text { 2015). }\end{array}$ & 2 \\
\hline Japan (0.5 ppm) (Kim et al., 2011) & $0.5-0.75 \mathrm{ppm}$ & $\begin{array}{l}\text { Eczema and changes in lung function have been } \\
\text { observed at } 0.6 \text { to } 1.9 \mathrm{ppm} \text { (ATSDR, 2015). }\end{array}$ & 4 \\
\hline OSHA (0.75 ppm) (NIOSH, 2007) & $0.75-1 \mathrm{ppm}$ & & 8 \\
\hline Australia (1 ppm) (Kim et al., 2011) & $>1 \mathrm{ppm}$ & $\begin{array}{l}\text { It is likely that low levels (<1 ppm) of formaldehyde } \\
\text { can have only a minimal (or non-existent) } \\
\text { carcinogenic potential on human cancer risk (Kim et } \\
\text { al., 2011). }\end{array}$ & 15 \\
\hline
\end{tabular}

\section{RESULTS AND DISCUSSION}

Formaldehyde concentrations

Formaldehyde has been measured during working hoursin March 2018 in 5 mortuaries as shown in Table 6. Suction fans didn't work in mortuaries (1 to 4) during measurements (this is the default status in them), while in the mortuary (5), it was working well. FA measurements in the mortuary (1) were repeated to test the suction efficiency. Also, FA was measured near the dead bodies' basin as it represents a major source for FA. Finally, FA was measured outside mortuaries.Results indicated that mean FA concentrations exceeded AQLs (Ceiling) of EEAA in all sites except mortuary (5). According to OSHA, 5 sites exceeded AQLs (TWA 8 ) while, 3 sites (Mortuary (1) "suction fans ON", Mortuary (5), and outside mortuaries) recorded concentrations within AQLs. According to NIOSH, all sites exceeded AQLs (TWA 8 ). The area near the dead bodies' basin recorded the highest FA concentration $(2.21 \mathrm{ppm})$ which represents about 6 folds of AQLs (Ceiling) of EEAA. 
Vol. 5, No. 03; 2020

ISSN: $2456-8643$

Table 6: Range, mean, and standard deviation of FA concentrations at various sites inside the working environment of medicine faculty mortuaries, Egypt (March 2018)

\begin{tabular}{|c|c|c|c|c|c|c|c|c|}
\hline Code & Site Description & $\mathrm{n}^{(*)}$ & $\begin{array}{l}\text { Max. } \\
(\mathrm{ppm})\end{array}$ & $\begin{array}{l}\text { Min. } \\
(\mathrm{ppm})\end{array}$ & $\begin{array}{c}\text { Mean } \pm \text { SD } \\
(\mathrm{ppm})\end{array}$ & $\begin{array}{c}\text { OSHA } \\
\left(\mathrm{TWA}_{8}\right)\end{array}$ & $\begin{array}{l}\mathrm{NIOSH} \\
\left(\mathrm{TWA}_{8}\right)\end{array}$ & $\begin{array}{c}\text { EEAA } \\
\text { (Ceiling) }\end{array}$ \\
\hline 01 & $\begin{array}{c}\text { Mortuary (1) } \\
\text { (suction fans OFF) }\end{array}$ & 56 & 3.40 & 0.62 & $1.69 \pm 0.72$ & \multirow{8}{*}{$\begin{array}{l}0.75 \\
\text { ppm }\end{array}$} & \multirow{8}{*}{$\begin{array}{l}0.016 \\
\text { ppm }\end{array}$} & \multirow{8}{*}{$\begin{array}{l}0.37 \\
\text { ppm }\end{array}$} \\
\hline 02 & $\begin{array}{c}\text { Mortuary (2) } \\
\text { (suction fans OFF) }\end{array}$ & 65 & 2.96 & 0.39 & $1.80 \pm 0.69$ & & & \\
\hline 03 & $\begin{array}{c}\text { Mortuary (3) } \\
\text { (suction fans OFF) }\end{array}$ & 67 & 2.36 & 0.02 & $0.94 \pm 0.56$ & & & \\
\hline 04 & $\begin{array}{c}\text { Mortuary (4) } \\
\text { (suction fans OFF) }\end{array}$ & 27 & 1.70 & 0.43 & $1.08 \pm 0.33$ & & & \\
\hline 05 & $\begin{array}{c}\text { Mortuary (5) } \\
\text { (suction fans ON) }\end{array}$ & 14 & 0.22 & 0.08 & $0.13 \pm 0.05$ & & & \\
\hline 06 & $\begin{array}{c}\text { Mortuary (1) } \\
\text { (suction fans ON) }\end{array}$ & 19 & 0.99 & 0.16 & $0.49 \pm 0.30$ & & & \\
\hline 07 & $\begin{array}{l}\text { Near the dead bodies' } \\
\text { basin }\end{array}$ & 35 & 2.64 & 1.85 & $2.21 \pm 0.20$ & & & \\
\hline 08 & $\begin{array}{l}\text { Outside mortuaries } \\
\text { (corridor) }\end{array}$ & 7 & 0.56 & 0.49 & $0.53 \pm 0.02$ & & & \\
\hline
\end{tabular}

There are few Published papers that measured FA in mortuaries. Suruda et al. (1993) recorded that the average FA air concentration during embalming courses in Cincinnati College of Mortuary Science (CCMS) was $1.4 \mathrm{ppm}$ with a range of $0.15-4.3 \mathrm{ppm}$. Also, Roland et al. (2019)found that the mean $\mathrm{TWA}_{8}$ concentration of formaldehyde in public and private mortuaries was $2.42 \pm 1.77$ and $2.52 \pm 0.99 \mathrm{ppm}$ respectively. On the other hand, a distinct study in Netherlands indicated that FA concentrations in mortuaries can be reduced significantly. Over a period of 6 years mitigating measures were introduced, including technical improvement and organizational changes. Geometric mean (GM) concentrations of FA in the breathing zone over a work-shift were $123 \mu \mathrm{g} / \mathrm{m}^{3}(0.0985 \mathrm{ppm})$ in 2012 and $114 \mu \mathrm{g} / \mathrm{m}^{3}(0.0913 \mathrm{ppm})$ in 2014. This exposure was reduced to an average of $28.8 \mu \mathrm{g} / \mathrm{m}^{3}(0.023 \mathrm{ppm})$ in 2017Scheepers et al. (2018). 
International Journal of Agriculture, Environment and Bioresearch

Vol. 5, No. 03; 2020

ISSN: $2456-8643$

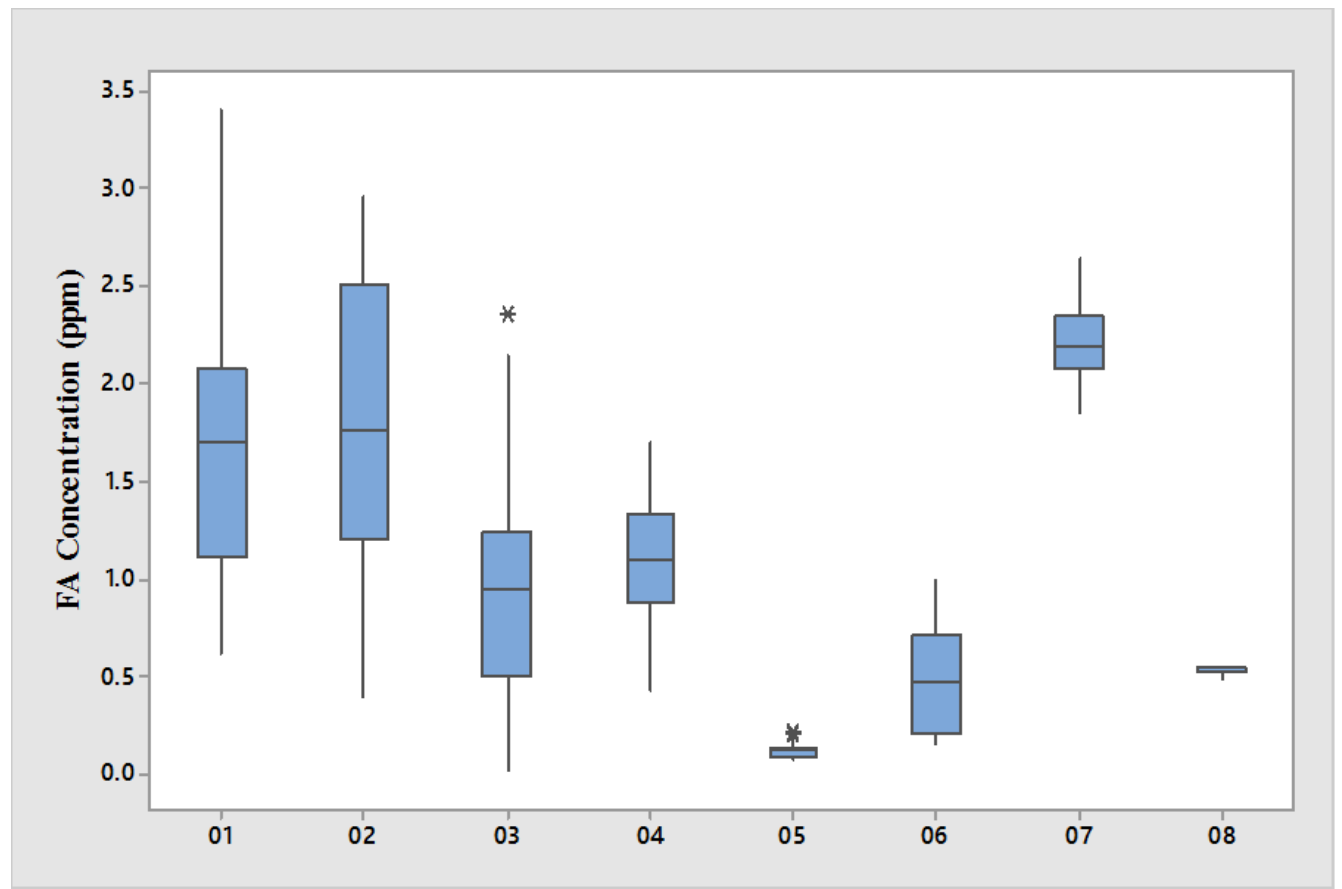

Fig. 4: Boxplot of measured FA concentrations (ppm) in the mortuaries

“using Minitab ${ }^{\circledR}$ 17.1.0”

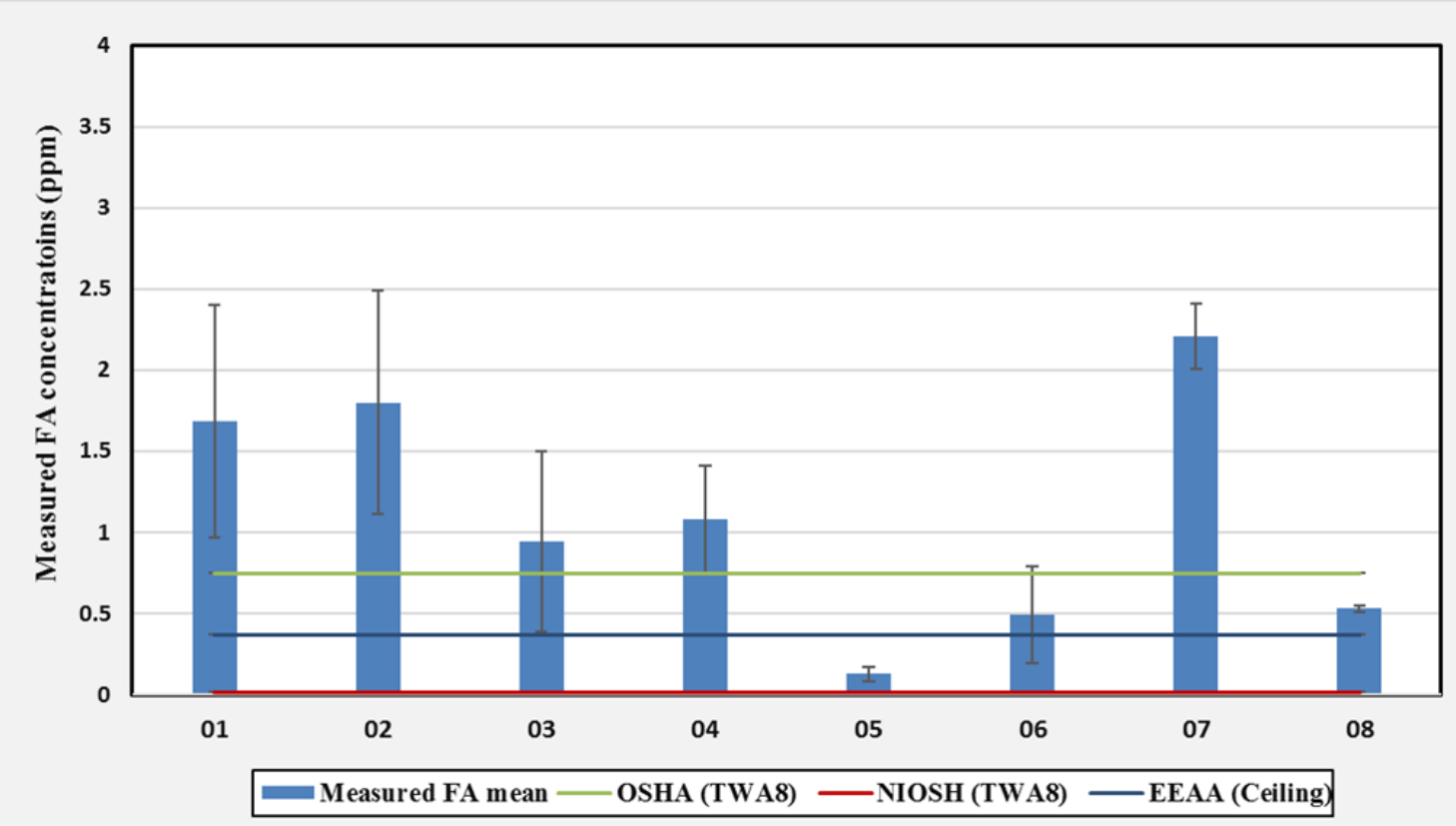

Fig. 5: Comparing FA mean concentrations (ppm) in the mortuaries to AQLs 


\section{Measurements of Ventilation Rates}

The full capacity of air regeneration by the suction fans in the five mortuaries was calculated and compared to EEAA minimum acceptable regeneration rate as shown in Tables 7 and 8.The mortuaries were considered as a science laboratory.

- Minimum acceptable regeneration rate $=8.6 \mathrm{l} / \mathrm{s} /$ person

- Occupancy density = 25 person $/ 100 \mathrm{~m}^{2}$ (If actual occupancy density is higher than 25 person/ $100 \mathrm{~m}^{2}$, the greater value is used in calculating the air regeneration rate).

Results of calculations indicated that the full capacity air regeneration rates by suction fans $\left(\mathrm{m}^{3} / \mathrm{s}\right)$ inside the mortuaries were (theoretically) higher than the minimum EEAA acceptable regeneration rate. But actually, except the $5^{\text {th }}$ mortuary, the capacity of suction fans decreased to $15 \%$ (as a maximum) from its full capacity. Also, medical students usually asked mortuaries workers to stop them during practical sections because of its noise and then FA recorded high concentrations as shown above in these mortuaries.

Table 7: Shown EEAA minimum acceptable regeneration rate in the five mortuaries

\begin{tabular}{|c|c|c|c|c|c|c|c|c|}
\hline \multirow{2}{*}{$\begin{array}{c}\text { Mortuary } \\
\text { No. }\end{array}$} & \multicolumn{3}{|c|}{ Mortuaries dimensions } & \multirow{2}{*}{$\begin{array}{l}\text { Area } \\
\left(m^{2}\right)\end{array}$} & \multirow{2}{*}{$\begin{array}{l}\text { Volume } \\
\qquad\left(\mathrm{m}^{3}\right)\end{array}$} & \multirow{2}{*}{ No. of people ${ }^{(*)}$} & \multirow{2}{*}{$\begin{array}{l}\left.\text { Occupancy density }{ }^{(* *}\right) \\
\left.\text { (person } / 100 \mathrm{~m}^{2}\right)\end{array}$} & \multirow{2}{*}{$\begin{array}{l}\text { Minimum acceptable } \\
\text { ventilation rate }{ }^{(* * *)} \\
\qquad\left(\mathrm{m}^{3} / \mathrm{s}\right)\end{array}$} \\
\hline & $\begin{array}{l}\text { Length } \\
(\mathrm{m})\end{array}$ & $\begin{array}{l}\text { Width } \\
(\mathrm{m})\end{array}$ & $\begin{array}{l}\text { Height } \\
(\mathrm{m})\end{array}$ & & & & & \\
\hline M. 1 & 12.6 & 10.7 & 2.9 & 134.8 & 391.0 & $\sim 100$ & 74 & 0.86 \\
\hline M. 2 & 15.0 & 12.5 & 2.9 & 187.5 & 543.8 & $\sim 100$ & 53 & 0.86 \\
\hline M. 3 & 12.1 & 10.6 & 2.9 & 128.3 & 372.0 & $\sim 100$ & 78 & 0.86 \\
\hline M. 4 & 12.0 & 4.0 & 2.9 & 48.0 & 139.2 & $\sim 80$ & 167 & 0.688 \\
\hline M. 5 & 6.1 & 6.0 & 2.9 & 36.6 & 106.1 & $\sim 45$ & 122 & 0.387 \\
\hline \multicolumn{9}{|c|}{$\begin{array}{l}(*) \text { No. of people: the total no. of peoples inside mortuaries including workers, medical students, and teaching assistants } \\
\left.\left({ }^{* *}\right) \text { Occupancy density (person } / 100 \mathrm{~m}^{2}\right)=(\text { Total no. of peoples } * 100) / \text { Area }\left(\mathrm{m}^{2}\right)\end{array}$} \\
\hline
\end{tabular}


International Journal of Agriculture, Environment and Bioresearch

Vol. 5, No. 03; 2020

ISSN: $2456-8643$

Table 8: shown calculations of air regeneration by the suction systems (full capacity)

\begin{tabular}{|c|c|c|c|c|c|c|}
\hline \multirow{2}{*}{$\begin{array}{c}\text { Mortuary } \\
\text { No. }\end{array}$} & \multicolumn{2}{|c|}{$\begin{array}{l}\text { Suction fan (Type :1) } \\
\text { (Capacity = } 3400 \mathrm{~m}^{3} / \mathrm{h} \text { ) }\end{array}$} & \multicolumn{2}{|c|}{$\begin{array}{l}\text { Suction fan (Type :2) } \\
\text { (Capacity }=1800 \mathrm{~m}^{3} / \mathrm{h} \text { ) }\end{array}$} & \multirow{2}{*}{$\begin{array}{l}\text { Regeneration rate } \\
\text { by suction }(1)+(2) \\
\qquad\left(\mathrm{m}^{3} / \mathrm{h}\right)\end{array}$} & \multirow{2}{*}{$\begin{array}{c}\text { Regeneration rate by } \\
\text { suction }(1)+(2) \\
\left(\mathrm{m}^{3} / \mathrm{s}\right)\end{array}$} \\
\hline & No. & Total $\left(\mathrm{m}^{3} / \mathrm{h}\right)$ & No. & Total $\left(\mathrm{m}^{3} / \mathrm{h}\right)$ & & \\
\hline M. 1 & 4 & 13600 & 0 & -- & 13600 & 3.78 \\
\hline M. 2 & 5 & 17000 & 3 & 5400 & 22400 & 6.22 \\
\hline M. 3 & 4 & 13600 & 0 & -- & 13600 & 3.78 \\
\hline M. 4 & 2 & 6800 & 0 & -- & 6800 & 1.89 \\
\hline M. 5 & 2 & 6800 & 0 & -- & 6800 & 1.89 \\
\hline
\end{tabular}

\section{Risk assessment}

In addition to measured FA concentrations, other data about working periods in mortuaries were collected as shown in Table 9. HRNs were calculated using Eq. 1 for the five mortuaries as shown in Tables 10,11, and 12. Calculated HRN was corresponded to unacceptable risk for workers, teaching assistants, and students in M.1, M.2, and M.4. HRN for M.3 was lower than them because FA concentration was slightly lower than them. The lowest calculated HRN noticed in M.5 (corresponded to the lowest FA concentration).

Table 9: Data of exposed persons to FA in mortuaries

\begin{tabular}{|c|c|c|c|c|c|c|}
\hline & Exposed people & M. 1 & M. 2 & M. 3 & M. 4 & M. 5 \\
\hline \multirow{3}{*}{$\begin{array}{c}\text { Mortuaries } \\
\text { Workers }\end{array}$} & Total number & 3 & 3 & 3 & 3 & 3 \\
\hline & Working days per week & 5 & 5 & 5 & 5 & 5 \\
\hline & Working hours per day & 9 & 9 & 9 & 9 & 9 \\
\hline \multirow{3}{*}{$\begin{array}{l}\text { Teaching } \\
\text { assistants }\end{array}$} & Total number & 4 & 4 & 4 & 4 & 4 \\
\hline & Working days (in mortuaries) per week & 4 & 4 & 4 & 4 & 4 \\
\hline & Working hours (in mortuaries) per day & 2 & 2 & 2 & 2 & 2 \\
\hline \multirow{4}{*}{$\begin{array}{l}\text { Medical } \\
\text { Students }\end{array}$} & Total number of sections in each mortuary per week & 24 & 24 & 24 & 24 & 24 \\
\hline & Total number of students per section & $\sim 100$ & $\sim 100$ & $\sim 100$ & $\sim 80$ & $\sim 45$ \\
\hline & Duration of each section (hrs.) & 2 & 2 & 2 & 2 & 2 \\
\hline & No. of sections for each student per week & 4 & 4 & 4 & 4 & 4 \\
\hline
\end{tabular}


Table 10: Calculations of HRN and corresponding risk and action time for mortuaries workers

\begin{tabular}{ccccccccc}
\hline Mortuary No. & LO & FE & DPH & NP & HRN & RISK & Action Time \\
\hline M. 1 & 15 & 4 & 15 & 2 & 1800 & Unacceptable & Stop the activity \\
\hline M. 2 & 15 & 4 & 15 & 2 & 1800 & Unacceptable & Stop the activity \\
\hline M. 3 & 15 & 4 & 8 & 2 & 960 & Extreme & Immediate Action \\
\hline M. 4 & 15 & 4 & 15 & 2 & 1800 & Unacceptable & Stop the activity \\
\hline M. 5 & 15 & 4 & 1 & 2 & 120 & Very High & Action within 1 week \\
\hline
\end{tabular}

Table 11: Calculations of HRN and corresponding risk and action time for teaching assistants

\begin{tabular}{|cccccc|c|c|}
\hline Mortuary No. & LO & FE & DPH & NP & HRN & RISK & Action Time \\
\hline M. 1 & 15 & 2.5 & 15 & 2 & 1125 & Unacceptable & Immediate Action \\
\hline M. 2 & 15 & 2.5 & 15 & 2 & 1125 & Unacceptable & Immediate Action \\
\hline M. 3 & 15 & 2.5 & 8 & 2 & 600 & Extreme & Action within 1 day \\
\hline M. 4 & 15 & 2.5 & 15 & 2 & 1125 & Unacceptable & Immediate Action \\
\hline M. 5 & 15 & 2.5 & 1 & 2 & 75 & High & Action within 1 month \\
\hline
\end{tabular}

Table 12: Calculations of HRN and corresponding risk and action time for medical students

\begin{tabular}{|ccccccc|c|c|}
\hline Mortuary No. & LO & FE & DPH & NP & HRN & RISK & Action Time \\
\hline M. 1 & 15 & 1.5 & 15 & 12 & 4050 & Unacceptable & Stop the activity \\
\hline M. 2 & 15 & 1.5 & 15 & 12 & 4050 & Unacceptable & Stop the activity \\
\hline M. 3 & 15 & 1.5 & 8 & 12 & 2160 & Unacceptable & Immediate Action \\
\hline M. 4 & 15 & 1.5 & 15 & 12 & 4050 & Unacceptable & Stop the activity \\
\hline M. 5 & 15 & 1.5 & 1 & 12 & 270 & Very High & Action within 1 week \\
\hline
\end{tabular}

\section{Risk Management}

Exposure to high concentrations of FA is a major problem in mortuaries, especially in developing countries, and need a lot of precautions to protect workers, medical students, and teaching assistants from the serious health risks caused by FA. In this work, several precautions are suggested to decrease this risk as shown in Table 14. 


\section{Table 13: Risk control options for FA emissions in mortuaries}

\begin{tabular}{|c|c|}
\hline Risk control level & Available precautions \\
\hline Elimination & $\begin{array}{l}\text { 1. The risk of exposure to FA emissions in mortuaries can be eliminated by using virtual reality } \\
\text { (VR) and augmented reality (AR) as effective and capable resources for anatomy teaching in } \\
\text { terms of both academic achievement and student satisfaction (Heather et al., 2019).But VR } \\
\text { and AR can't eliminate this risk completely as Saltarelli et al. (2014) found that the human } \\
\text { cadaver laboratory offered a significant advantage over the multimedia simulation program } \\
\text { on cadaver-based measures of identification and explanatory knowledge. } \\
\text { 2. Also, this risk can be eliminated by using human-tissue-mimicking materials such as natural } \\
\text { rubber nanocomposite, silicon, and Polyvinyl Chloride (PVC) instead of human cadavers } \\
\text { (Murniatia et al.,2017; Wanget al., 2014; Li et al., 2015). }\end{array}$ \\
\hline Substitution & $\begin{array}{l}\text { 3. Phenoxyethanol is suggested to be a substitute for formaldehyde in preservation of dead } \\
\text { bodies (Frølich et al.,1984). Also, Ethyl alcohol and polyethylene glycol (Kryofix) and } \\
\text { Glutaraldehyde are suggested as potential alternatives(Mao et al.,1994). There are several } \\
\text { substances used in modern anatomical embalming instead of FA but none is the subject of } \\
\text { consensus(Goyeret al., 2006; Brenneret al., 2014).Kumar et al. (2014)reported that "it is } \\
\text { impractical to find out non-toxic embalming solution" } \\
\text { 4. Substitution with lower concentration of formaldehyde solution(Elshaer et al., 2017). }\end{array}$ \\
\hline Engineering & $\begin{array}{l}\text { 5. Well ventilation in mortuaries decreases FA concentrations and hence decreases its risk, but } \\
\text { it is generally recognized the operation of ventilation systems is one of the noisy activities } \\
\text { which causes students to be distracted (Students usually asked the mortuary' workers to } \\
\text { stop the ventilation system!). This problem can be solved by adding inertia blocks to } \\
\text { increase the stability of the ventilation system, providing flexible connectors between the } \\
\text { fan and associated ducts, using sound-absorbing materials ... etc.(EPD,2006). } \\
\text { 6. Leak prevention: by closing every probable source of FA emissions such as pools in which the } \\
\text { dead parts are collected after practical sections (in this study, FA concentrations near them } \\
\text { were very high). The cover would only have to be opened for introduction or removal of } \\
\text { specimens(Scheepers et al., 2018). }\end{array}$ \\
\hline Administrative & $\begin{array}{l}\text { 7. Instead of collecting the leak drained fluid in an absorbent disposable tissue and an open } \\
\text { bucket to collect any formalin dripping from the tables, (allowing the FA to evaporate from } \\
\text { this secondary source) the drained liquid would be removed and collected in a closed } \\
\text { containment (Scheepers et al., 2018). } \\
\text { 8. Optimizing storage system by storage of specimens needed for a specific class/course in one } \\
\text { or a few labelled tanks to reduce on the number of tanks to be opened to retrieve the } \\
\text { required specimens (Scheepers et al.,2018). } \\
\text { 9. Workers should get out of the morgue periodically to breathe clean air outside and not be in } \\
\text { the morgue unnecessarily. } \\
\text { 10. Imposing sanctions on any worker or a student entering the morgue without wearing } \\
\text { respirators }\end{array}$ \\
\hline PPES & and teaching assistants must wear suitable masks, eyeglasses, and gloves \\
\hline
\end{tabular}


Vol. 5, No. 03; 2020

ISSN: $2456-8643$

\section{Risk communications}

All risk control precautions will be useless without increase awareness of people at risk and administrative board. In this study, suction fans can decrease FA concentrations but workers and students choose to stop them and don't care about the risk of FA accumulation in the mortuaries. Awareness lectures, posters, and workshops must be conducted periodically for workers and students.

\section{CONCLUSION}

FA recorded concentrations higher than AQLs of EEAA (Ceiling), OSHA (TWA 8 ), and NIOSH $\left(\mathrm{TWA}_{8}\right)$ in four mortuaries. M.05 only recorded concentration lower than AQLs of EEAA (Ceiling) and OSHA (TWA 8 ) but still higher than $\mathrm{NIOSH}$ (TWA 8 ). The highest FA concentration was recorded near the dead bodies' basin.

Ventilation system capacity was calculated and air regeneration rates inside all mortuaries were (theoretically) higher than the minimum EEAA acceptable regeneration rate. But actually, except the $5^{\text {th }}$ mortuary, the capacity of suction fans decreased to $15 \%$ (as a maximum) from its full capacity. Also, medical students usually asked mortuaries workers to stop them during practical sections because of its noise.

Calculated HRN corresponded to unacceptable risk for workers, medical students, and teaching assistants in M.1, M.2, and M.4. HRN of M.3 was lower than them for workers and teaching assistants but still in the level of extreme risk for workers and for students. The lowest calculated HRN noticed in M.5 and its risk considered high for workers and for students. These results indicated that working and education sessions in mortuaries are risky and need several precautions.

According to risk control hierarchy, several precautions were suggested to control FA risk such as using of virtual reality (VR) and augmented reality (AR) for anatomy teaching, using of human-tissue-mimicking materials instead of human cadavers,substitution of FA with other preservative solutions that have less toxicity, use of less concentrated formaldehyde solutions, well ventilation with noise decreasing measures, good closing of pools of preservation, administrative controls, and wearing suitable PPEs usually inside mortuaries.Finally, the study indicated that;

1. HRN system can be used as a preliminary risk assessment tool that can be calculated by non-specialists to take decisions when high FA concentration is detected.

2. Risk communication activities are needed to increase awareness of workers and students about FA health risks.

3. There are several control options that need further scientific studies such as using of VR and AR in anatomy sessions, decreasing noise of ventilation systems, and substitution of formaldehyde by other preservative solutions. 


\section{ACKNOWLEDGEMENT}

AMATEC Consulting Foundation supported this study for Environmental and Scientific Assistance.

\section{CONFLICT OF INTEREST}

The author declares that there is no conflict of interests regarding the publication of this manuscript. In addition, the ethical issues, including plagiarism, informed consent, misconduct, data fabrication and/or falsification, double publication and/or submission, and redundancy have been completely observed by the authors.

\section{ABBREVIATIONS}

\begin{tabular}{|c|c|}
\hline$A Q L$ & AirQuality Limit \\
\hline$A T S D R$ & Agency for Toxic Substances and Disease Registry \\
\hline$A R$ & Augmented Reality \\
\hline CCMS & Cincinnati College of Mortuary Science \\
\hline$D P H$ & Degree of Possible Harm \\
\hline$E E A A$ & Egyptian Environmental Affairs Agency \\
\hline$E P D$ & Environmental Protection Department \\
\hline$F A$ & Formaldehyde \\
\hline$F A O$ & Food and Agriculture Organization \\
\hline$F E$ & Frequency of Exposure \\
\hline$G M$ & Geometric mean \\
\hline$H H S$ & Health and Human Services \\
\hline$H R N$ & Hazard Rating Number \\
\hline IARC & International Agency for Research on Cancer \\
\hline LO & Likelihood of Occurrence \\
\hline I/s/person & liter/second/person \\
\hline$m^{2}$ & Square meters \\
\hline$m^{3} / h$ & Cubic meters per hour \\
\hline $\mathrm{m}^{3} / \mathrm{s}$ & Cubic meters per second \\
\hline$n$ & total number of samples \\
\hline $\mathrm{NIOSH}$ & National Institute for Occupational Safety and Health \\
\hline$N P$ & Number of Persons at risk \\
\hline OGTR & Office of the Gene Technology Regulator \\
\hline OSHA & Occupational Safety and Health Administration \\
\hline PEL & Permissible Exposure Limit \\
\hline$P I D$ & Photoionization detector \\
\hline$P P E$ & Personal Protective Equipment \\
\hline ppm & part per million \\
\hline$S D$ & Standard Deviation \\
\hline SHP & Safety and Health Practitioner \\
\hline STEL & Short Time Exposure Limit \\
\hline$T W A_{8}$ & Time-weighted Average ( 8 hours) \\
\hline UV & Ultra Violet \\
\hline$\mu g / m^{3}$ & microgram per cubic meter \\
\hline VOCs & Volatile Organic Compounds \\
\hline$V R$ & Virtual Reality \\
\hline WHO & World Health Organization \\
\hline
\end{tabular}




\section{REFERENCES}

ATSDR, (2015). Formaldehyde - ToxFAQs ${ }^{\mathrm{TM}}$. Atlanta, GA: U.S. Department of Public Health and Human Services, Public Health Service.Agency for Toxic Substances and Disease Registry.

https://www.atsdr.cdc.gov/tfacts111.pdf

Alessandro, A.; Giovanna, S.; Stefano, M.; Stefania, C.; Vanessa, I.; Roberta, E.; Andrea, G. A.; Concetto, G.; Sebastiano, G.; Caterina, M., (2019). Formaldehyde exposure and acute myeloid leukemia: a review of the literature. Medicina, 55(10): 638-646 (9 pages).

https://www.ncbi.nlm.nih.gov/pmc/articles/PMC6843642/

Brenner, E., (2014). Human body preservation - old and new techniques. J Anat., 224(3): 316344 (29 pages).

https://www.ncbi.nlm.nih.gov/pmc/articles/PMC3931544/

EEAA, (2011). Egyptian Prime Minister's Decree No. 1095 of 2011 to amend the executive regulations of the egyptian environment law.

http://www.eeaa.gov.eg/en-us/laws/envlaw.aspx (Arabic version only)

Elshaer, N. S. M.;Mahmoud, M. A. E., (2017). Toxic effects of formalin-treated cadaver on medical students, staff members, and workers in the Alexandria faculty of medicine. Alexandria Journal of Medicine, 53(4): 337-343 (7 pages).

https://doi.org/10.1016/j.ajme.2016.11.006

EPD, (2006). Good practices on ventilation system noise control. Hong Kong.Environmental Protection Department

https://www.epd.gov.hk/epd/sites/default/files/epd/english/environmentinhk/noise/guide_ref/files /Vent sys E-06 0.pdf

Frølich, K.W.; Andersen, L.M.; Knutsen, A.; Flood, P.R., (1984). Phenoxyethanol as a nontoxic substitute for formaldehyde in long-term preservation of human anatomical specimens for dissection and demonstration purposes. Anat Rec., 208(2):271-278 (8 pages).

https://www.ncbi.nlm.nih.gov/pubmed/6703343

Goyer, N.; Egin, D.; Beaudry, C.; Bouchard, M.; Carrier, G.; Lavoué, J.; Noisel, N.; Gérin, M., (2006). Formaldehyde in the workplace: prevention guide. Institut de recherche RobertSauvé en santé et en sécurité du travail (IRSST).

https://www.irsst.qc.ca/en/publications-tools/publication/i/100211/n/formaldehyde-in-theworkplace-prevention-guide-rg-473 
Heather, A.; Chinnah, T.; Devaraj, V., (2019). The use of virtual and augmented reality in anatomy teaching. MedEdPublish (8 pages).

https://www.mededpublish.org/manuscripts/2195

IARC, (2012). Chemical agents and related occupations. In IARC monographs on the evaluation of carcinogenic risks to humans, International Agency for Research on Cancer: Lyon, France.

http://publications.iarc.fr/Book-And-Report-Series/Iarc-Monographs-On-The-Identification-OfCarcinogenic-Hazards-To-Humans/Chemical-Agents-And-Related-Occupations-2012

Ion Science, (2009). FirstCheck 4000 and 6000 Ex user manual V2.7. Ion Science Ltd., The Way, Fowlmere,Cambs, SGB 7UJ, UK.

http://eonpro.americommerce.com/manuals/FirstCheckManualV2.7.pdf

Kim, K.; Jahan, S.A.; Lee, J., (2011). Exposure to formaldehyde and its potential human health hazards. J. Environ. Sci. Health., Part C Environ. Carcinog. Ecotoxicol. Rev., 29(4): 277299 (23 pages).

https://www.ncbi.nlm.nih.gov/pubmed/22107164

Kumar, R.; Verma, R. K.; Dixit, R. K.; Kumar, N.; Kumar, N.; Katiyar, D.K., (2013). Embalming solutions and their adverse effects: an update. Asian J. Pharm. Hea. Sci., 3(2): 735-738 (4 pages).

http://ajphs.com/article/2013/3/2/735-738

Li, W.; Belmont, B.; Shih, A., (2015). Design and manufacture of polyvinyl chloride (PVC) tissue mimicking material for needle insertion. Procedia Manufacturing, (1): 866-878 (13 pages).

https://www.sciencedirect.com/science/article/pii/S2351978915010781

Mao, C.; Woskie, S., (1994). Formaldehyde use reduction in mortuaries. Toxics Use Reduction Institute. University of Massachusetts Lowell.

https://www.turi.org/content/download/8158/139692/file/1994\%20Report\%2024\%20Mao\%20an d\%20Woskie\%20-\%20Formaldehyde\%20Use\%20Reduction\%20in\%20Mortuaries.pdf

Murniatia, R.; Sutisnaa; Wibowoa, E.; Rokhmata, M.; Iskandara, F.; Abdullaha, M., (2017). Natural rubber nanocomposite as human-tissue-mimicking materials for replacement cadaver in medical surgical practice. Procedia Eng., 170:101-107 (7 pages).

https://www.sciencedirect.com/science/article/pii/S187770581731130X 
NIOSH, (2007). Niosh pocket guide to chemical hazards( $1^{\text {st }}$ ed. $)$. Department of health and human services, centers for disease control and prevention, national institute for occupational safety and health.

https://www.cdc.gov/niosh/idlh/50000.html

NIOSH, (2015).Hierarchy of controls. Centers for Disease Control and Prevention (CDC). National Institute for Occupational Safety and Health.

https://www.cdc.gov/niosh/topics/hierarchy/

Nauta, M. J.; Andersen, R.; Pilegaard, K.; Pires, S. M.; Ravn-Haren, G.; Tetens, I.; Poulsen, M., (2018). Meeting the challenges in the development of risk-benefit assessment of foods. Trends Food Sci., 76: 90-100 (11 pages).

https://www.sciencedirect.com/science/article/pii/S0924224416305775

Obed-Whyte, R.; Douglas K. E.; Akaranta O., (2019). Comparative assessment of formaldehyde concentrations in public and private mortuaries in rivers state, Nigeria. J. Sci. Res. Rep., 23(2): 1-11 (11 pages).

http://www.journaljsrr.com/index.php/JSRR/article/view/30115

OGTR, (2009). Risk analysis framework April 2009. Office of the Gene Technology Regulator Commonwealth of Australia.

http://www.isaaa.org/workshop/2012-01-10-

bangkok/download/environmental_risk_assessment/Australia-

OGTR RiskAnalysisFramework 2009 raffinal4(2).pdf

Roland, O.-W.; Douglas, K. E.; Akaranta, O., (2019). Comparative Assessment of formaldehyde concentrations in public and private mortuaries in rivers state, Nigeria. J. Sci. Res. Rep., 23(2): 1-11 (11 pages).

http://journaljsrr.com/index.php/JSRR/article/view/30115

Safety and Health Practitioner (SHP), (2015). Risk estimation: 25 years on.

https://www.shponline.co.uk/blog/risk-estimation-25-years/

Saltarellim A.J.; Roseth, C.J.; Saltarelli, W.A., (2014). Human cadavers Vs. multimedia simulation: A study of student learning in anatomy. Anat. Sci. Educ., 7(5):331-339 (9 pages).

https://www.ncbi.nlm.nih.gov/pubmed/24415563

Scarselli, A.; Corfiati, M.; Di Marzio, D.; Iavicoli, S., (2017). National estimates of exposure to formaldehyde in italian workplaces. Ann. Work Expo. Health, 61(1): 33-43 (11 pages).

https://www.ncbi.nlm.nih.gov/pubmed/28395310 
Scheepers, P. T. J.; Graumans, M. H. F.; Beckmann, G.; Dael, M.; Anzion, R. B. M.; Melissen, M.;Pinckaers, N.; Wel, L.; Werdt, L. M. A.; Gelsing, V.; Linge, A., (2018). Changes in work practices for safe use of formaldehyde in a university-based anatomy teaching and research facility. Int. J. Environ. Res. Public Health. 15(9): 2049-2070 (22 pages).

https://www.ncbi.nlm.nih.gov/pmc/articles/PMC6164304/

Sousa, M.; Mendes, C.; Lança, A.; Paixão, S.; Ferreira, A., (2017). Assessment and control of occupational risks in hospital Morgues. Revista Portuguesa de Saúde Ocupacional 4 (9 pages).

https://www.researchgate.net/publication/322026732_ASSESSMENT_AND_CONTROL_OF_O CCUPATIONAL RISKS IN HOSPITAL MORGUES

Suruda, A.; Schulte, P.; Boeniger, M.; Hayes R. B.; Livingston, G. K.; Steenland, K.; Stewart, P.; Herrick, R.; Douthit, D.; Fingerhut, M. A., (1993). Cytogenetic effects of formaldehyde exposure in students of mortuary science. Cancer Epidemiol. Biomarkers Prev., 2(5):453-60 (8 pages).

https://www.ncbi.nlm.nih.gov/pubmed/8220090

TÜV SÜD Product Service, (2015). Practical guide to Machinery Safety (Edition 5).

https://www.tuvsud.com/en-gb/resource-centre/white-papers/practical-guide-to-machinerysafety-edition-5

Wang, Y.; Tai, B. L.; Yu, H.; Shih, A. J., (2014). Silicone-based tissue-mimicking phantom for needle insertion simulation. J. Med. Devices., 8(2): 021001 (7 pages).

https://asmedigitalcollection.asme.org/medicaldevices/articleabstract/8/2/021001/448103/Silicone-Based-Tissue-Mimicking-Phantom-for-

Needle?redirectedFrom=fulltext. 